\title{
Unmarried in Palestine: Embodiment and (dis)Empowerment in the Lives of Single Palestinian Women
}

\author{
Penny Johnson
}

\begin{abstract}
There are rising numbers of single women across the Arab world. While this is usually connected with delayed marriage, Palestine shows a unique pattern of early but not universal marriage. This article looks beneath the statistics to investigate the stories behind this trend. How do young unmarried women negotiate boundaries and understand and enact choice in the context of a society experiencing prolonged insecure and warlike conditions, political crisis and social fragmentation and where the high number of unmarried women can be an increasing locus of moral panic? In conducting focus groups with two generations of women, my research looks at the prevailing importance of education, civil society and security in negotiating space within women's lives and uncovers a long tradition of unmarried women leading full and significant lives which needs to be recovered from the past.
\end{abstract}

\section{Introduction}

The first national demographic surveys in Palestine (PCBS 2002, 2006a, 2006b) revealed an unusually high proportion of unmarried women in the West Bank and Gaza, while men were almost universally shown to be married. I wanted to find out why there were so many single women. As I began my research, my attention quickly shifted from the statistics to the narratives behind the numbers. These women's stories engaged me; from a life in service to the nation, told by older single women, to the tales of moral danger circulating around young unmarried women today. However, they also taught me to be cautious in applying the label 'unmarried'. The young women I first spoke with were not keen to be identified in this way, implying a permanent state of singlehood. The response of Wisam, ${ }^{1}$ an unmarried woman in her forties, living and working in Ramallah, to my request for an interview served as a warning to avoid any temptation to treat unmarried women in Palestine or elsewhere as a unitary category:

The project you are working on sounds very interesting. The problem is that I don't think I have much to contribute to this study. I don't see myself in those terms. I don't think the fact that I am unmarried has any significant advantages or disadvantages over what I choose to do privately or publicly.

Her words undermined the assumption that singlehood is at the centre of an unmarried woman's identity or perception of herself. It also implied that our interviews should be embedded in a broader life story approach in order to understand the significance or non-significance of being unmarried in the course of life events.

This article reflects on the voices of two generations of unmarried women (aged 19-29 and 45-68) from focus groups and topical life interviews which we conducted in the West Bank and Gaza between 2007 and 2008, ${ }^{2}$ to explore the diversity and commonalities in their lives in the context of a society experiencing prolonged warlike conditions, political crisis and social disruption. Using the lens of the 'body', I examine how these women negotiate their daily lives and the dynamics of choice for their futures.

\section{Demographic profiles}

Whilst in most of the Arab world the rising number of single women is connected with 
Table 1 Gaza and West Bank: proportion of never-married women

\begin{tabular}{|c|c|c|c|c|}
\hline \multirow[b]{2}{*}{ Age Range } & \multicolumn{2}{|c|}{2000} & \multicolumn{2}{|c|}{2004} \\
\hline & West Bank & Gaza & West Bank & Gaza \\
\hline $30-34$ & 14.8 & 8.5 & 16.1 & 9.3 \\
\hline $35-39$ & 16.1 & 8.5 & 13.2 & 8.7 \\
\hline $40-44$ & 12.3 & 6.4 & 11.7 & 3.5 \\
\hline
\end{tabular}

Source Halabi (2007: Table 4). Figures are based on calculations from the raw data.

delayed marriage, what is striking in Palestine, and requires explanation, is that Palestinian women in the West Bank and Gaza appear to have a 'unique marriage pattern: early but not universal' (Rashad et al. 2005: 3). Palestinian women marry (and bear children) at the median age of 18 , but there are significant numbers of women remaining single. Although official national statistics are only available from 1995, other surveys and research suggest that female singlehood has a longer historical trajectory.

As we can see from Table 1, rates of singlehood are consistently higher in the West Bank than Gaza. In Palestine in general almost one in ten women over 40 are never married compared to 1.5 per cent in Egypt and about 4 per cent in Jordan. In the Arab region, only Lebanon, Tunis and Algeria have a higher proportion of nevermarried women, and the first two have a considerably higher average marriage age for women (see Drieskens 2006 for Lebanon).

In reviewing data from the 2000 and 2004 Demographic and Health surveys in Palestine (PGBS 2000; PGBS 2004), it is clear that nevermarried women are clustered at opposing poles of education. For 2004, almost half of nevermarried women over 30 had only primary education or lower, while 22.9 per cent had above secondary education. Only 10.7 per cent of married women aged 30 and over had above secondary education. However, the gap widens with age, suggesting 'that educated women had more difficulty marrying in the past' (Halabi 2007: 39). Our focus groups confirmed the perception that, in combination with other factors like employment, post-secondary education has become an asset. Coupled with perceived earlier ages of marriage in certain settings (primarily rural), girls with only secondary education find themselves trapped, with diminishing marriage prospects on the one hand and lack of income opportunity on the other.

\section{The 'crisis' of unmarried women: regional and Palestinian discourses}

Wisam's words in the introduction neatly counter contemporary discourses which frame unmarried women as a 'crisis' in society. Media discourse across the Arab world - in the last decade in particular - present the growing number of single women as a problem (Ghazi 2006). Some reports seem to imply an epidemic that needs public intervention for the health of the society, for example the Khaleej Times read: 'Alarm bells ring as rate of UAE spinsters rises' and called for the 'involvement of all segments of the society as well as the authorities' to combat this 'alarming rate', given as an entirely improbable 73 per cent (Ibrahim 2004). It is fair, I think to consider the construction of this 'crisis' as a form of moral panic (Cohen 2002) whereby unmarried women are 'chastised by their societies' (Ghazi 2006) and come to represent social ills and cultural disorder. Media and public discourse also point to an unsettling of long-held cultural assumptions about the universality of marriage and raise questions about whether the 'cognitive frame of marriage' (Friedl 2003) has started to shift.

Although Palestine was late in joining the discourse around the single woman 'crisis', the issue has emerged strongly in recent years, triggered by the 'missing men' killed and injured in the second intifada. Islamist political movements (particularly Hamas) and Islamic charities and non-governmental organisations (NGOs) have embraced the mission of collective marriage ceremonies explicitly framed as reducing the social ill of unmarried women and 
allowing young men to marry cheaply (in an era of prohibitive wedding expenses). The number of male deaths from the second intifada is offered as an explanation both for the crisis and a justification for public action. The Hamas-led government and/or Islamic charities in Gaza staged ten collective ceremonies in 2008 for unmarried women and for war widows to remarry. 'There will be more weddings', said one organiser, 'no one will remain single' (ElKhoudary 2008). The 'epidemic' of unmarried women is thus partially socially constructed, reminding us that a moral panic does not imply that 'something does not exist' (Cohen 2002: vii) but does denote a form of cultural politics that crystallises public anxieties.

\section{Bodies, borders and bio-politics}

Two of the focus groups conducted in the Southern West Bank, one in Sair, a village in the Hebron area and the other in the Dheisheh refugee camp near Bethlehem, provide an example of how these public anxieties are demonstrated in women's everyday lives. Both communities are relatively disadvantaged and subject to Israeli military violence and profound insecurity. However, when asked about their hopes for the next five years, the young women in Sair said: 'There is nothing encouraging ahead of us', 'Everything is forbidden to us, we can't go to work or leave the house', and more disturbingly, 'Our life is over'. In stark contrast the women in Dheisheh planned to continue their education, get a job and marriage: 'A bachelor's degree is not enough, I need a master's' and 'I want to develop my personality and dreams'.

Why the striking difference in visions for the future? Why so much hope in Dheisheh and so much despair in Sair? In fact the groups showed that the aspirations of Sair and Dheisheh were more similar than appears. The women in Sair also expressed a desire for education and work outside the home, but the main difference was they felt these were impossible goals. The two groups of women were distinguished by four different social conditions. The first was access to education. Most of the young women in Sair had completed high school, but this level of education proved insufficient for work and marriage. In contrast, at least half the group in Dheisheh were either engaged in post-secondary education or aspired to it. Secondly, the supportive environment of civil society organisations in Dheisheh played a decisive role in encouraging the girls' dreams and offering opportunities for public involvement - as did the support of their families for their education (Rosenfeld 2004).

Thirdly, although both communities endure restrictions on movement, they are located within different regulative and protective environments. Young women from Dheisheh can go to Bethlehem - with its higher education institutes and wider opportunities for work - without crossing a checkpoint. In contrast, young women in Sair have to cross Israeli checkpoints to reach Hebron, and Palestinian police protection is only infrequently available. ${ }^{3}$ Significantly, Dheisheh's own internal security (both physically and socially) is also much stronger due to the camp's very active local committee. This impacts on the final difference: perceived and actual threats to female personal security, defined explicitly in terms of the body. In Sair, families placed severe restrictions on their unmarried daughters' mobility, due to the intertwined fears of physical and moral danger, whether from Israeli soldiers on the village outskirts or unruly young men on its streets. It also related to the so-called 'honour' killing of a young married woman in murky circumstances where a made-up pornographic image of her was circulated via mobile phones. Although murders of women under the rubric of 'honour crimes' are relatively few at 10-20 per year, ${ }^{4}$ the effects of this incident were drastic.

The victim was declared innocent by the imam of the local mosque, but young women were still barred from using the telephone and often from leaving their homes. The fear - and moral panic of the community was, in a literal way, 'embodied' in the restrictions placed on these young women's bodies and selves. Their narratives - and those circulated around them - are 'narratives of sexuality' in their focus on bodily vulnerability and threats to bodily and moral integrity. The perceived and actual physical and sexual threats to the bodies of young unmarried women point to their liminal status not only as markers of a normative female sexuality (Sa'ar 2004), but as representing threats and violations to the Palestinian body politic.

At the same time, young women can be agents of change, challenging borders and expanding boundaries. This emerges in the ambitions of the young women in Dheisheh, but is also evident 
even in the much more restricted circumstances of Sair. A female secondary school student explains that restrictions cause both despair and resolve among girls:

The suppression of girls'opinions and our culture of shame means families do not like their girls to study and rent places outside the village. This comes from hearing so much about the problems of girls, particularly honour crimes. This causes girls to be depressed but also causes them to cling to education.

This dynamic of restriction and resolve is a dynamic of bodies and boundaries that, as Butler notes, is central to the relationship of bodies and the world around them:

Not only did bodies tend to indicate a world beyond themselves, but this movement beyond their own boundaries, a movement of boundary itself, appeared to be quite central to what bodies 'are'. (Butler 1993: ix)

In the context of Palestine, bodies and boundaries are critical constituents of an Israeli politics of spatial segregation where an elaborate, shifting and growing matrix of control is formed by some 500 checkpoints or barriers that divide Palestinian towns and villages from each other. This checkpoint system has 'grown to govern the entire spectrum of Palestinian life under occupation' (Weizman 2007: 147). While Israeli settler bodies move freely, Palestinian bodies are contained and humiliated.

The translation of public insecurity, invasive violence and political corruption into moral danger is evident in Palestinian daily discourse, particularly in the circulation of rumours and sexualised narratives (Johnson 2007b). The discourses that surround unmarried women thus offer a lens to this complex present, as well as contrasts and continuities with the past where unmarried women's bodies in specific social and economic circumstances were conceived as in service to a national and social project. Older women (aged 45-65), interviewed at the beginning of this project, often expressed this sentiment, articulated by 52-year-old Mariam from Breij camp in Gaza: 'I wanted to be someone, to serve society'. This service was frequently seen as replacing marriage and advancing the national struggle against occupation. Coming back from her university studies in Cairo in 1971, Zahira
Kamal, who later became the first Minister of Women's Affairs in the Palestinian Authority noted: 'I was not thinking of marriage. It was the start of occupation and that was on my mind'. In contemporary Palestine, the notion of the body (and mind) in service to the nation has been radically reconfigured.

\section{Is education empowerment? The significance of location and mobility}

As we have seen above, education is a significant aspiration for many young unmarried Palestinian women. In the older generation, education, particularly post-secondary, was a key to individual autonomy, public service and social status - but sometimes a detriment to marriage. Educated women were valued as markers of a desired modernity. For Palestinian parents in the same post-1948 era, education was often seen as a form of portable capital in the insecure conditions of statelessness after the loss of Palestine. From the provision of free education by the United Nations Relief and Works Agency (UNRWA) to the founding of Palestinian universities in the West Bank and Gaza in the 1970s, education has been a venue for both mobility and security in the highly insecure circumstances of Palestinian life, and female educational levels have increased consistently. Indeed at present, young Palestinian women now have slightly higher enrolment rates in post-secondary education than their male counterparts.

In the older generation, the role of fathers in supporting their daughters' education is prominent. The father of Ilham (who later achieved a PhD in Linguistics and became a Birzeit University professor) told her: 'Ya binti, [O my daughter] there is no man in the world that is worth a university degree'. In focus groups with the young women, education remains a central goal, but its utility as an avenue to autonomy and/or public service varies. Unlike the earlier generation, post-secondary education is perceived to be a marriage asset if coupled with secure employment. Young women with less education, particularly those in villages who finish high school and remain at home, find themselves with diminishing marriage prospects. A young woman in her mid-twenties from Beit Fajjar, near Bethlehem, herself 'only' a high school graduate, observed ruefully, 'Only a "Doctora" [a PhD holder] can get married at a later age than 18 or 20 '. 
Where education is the sole improvement, the life of a young woman in rural or marginalised settings may not change too much. Samia, an Open University graduate from Tubas village in the Jordan Valley, expressed constraints on her movement imposed by community gossip and pressure:

I like to go to work. But people say, she is not an employee, why does she go? People interfere with everything. If I am walking in the street, they say 'this is not your day to go to work, what are you doing?'

Samia, like many of the young women in our groups who pursued higher education, was a student at the Jerusalem (Al Quds) Open University. For young women, the Open University offers an education which can be pursued within the safer confines of home (and village), with only occasional forays into student life. This also means that the potentially liberating atmosphere of the campus is largely absent. Selwa from Beit Fajjar said that she has been going to the Jerusalem Open University for three years but declared proudly 'I have never spoken to a young man'.

Amira, who is on the student council at the Hebron site of the Jerusalem Open University and from a powerful family in the area, has a confidence in her future that led her to turn down a cousin in marriage and to insist on a university education. She expresses her trajectory of education and employment in spatial terms, saying she has 'no borders':

In my family, I am the only one who entered the university. I am always active, even though people say 'Why go to the university and get tired?' For me there are no borders. My cousin asked for me but I didn't want. I want to go from the student council to a wazifeh [a secure job as an employee].

While she is buoyed by her class and family position (and her strong personality), her consciousness of a need to change and move is shared by other young women who may not have her personal and family assets.

\section{Marriage age, staying single and 'change'}

An interesting consensus emerged in all the focus groups that the best age for a young woman to marry was in her early to mid-twenties when she has her own personality; significantly later than the median age of 18 . However, particularly in village settings, most agreed that girls usually marry younger than this and that their marriage chances after that age were small. The young women in Sair concurred that prospective husbands 'really like a girl who is 15 or $16 \ldots 20$ maximum'. This gap between the ideals of young women (and often their mothers as well) and the reality of early marriage is a source of great tension, as well as potential for change. Hadeel, a young unmarried woman in her twenties from Shawawreh, a village on the arid Eastern slopes of Bethlehem, is unsuccessfully looking for work. She says: 'Women are more conscious now. They don't just marry anyone. There is a change'.

This feeling of change is also evident in the more prosperous village of Beit Fajjar. Basma, an unmarried women in her late thirties who looks after her elderly parents ${ }^{5}$ says that her mother inherited a house and land from her parents and will give it to Basma. 'Girls no longer accept everything. They want their rights'.

Yet the combined force of consciousness of rights, pride in education, and family trust does not seem to help these young women with their twin preoccupations of marriage and, almost obsessively, search for income-generating work. Opportunities are not only limited by the job market ${ }^{6}$ but by what is considered respectable being a teacher is fine, but being a secretary is described as 'difficult' due to the proximity of male staff and the threat of sexual harassment. Again, bodies are a source of danger and vulnerability. One young woman from Sair said, 'I took a course in computers for six months and then was forbidden to work'.

In terms of marriage, when we asked why families wanted a young bride of 15 or 16 , the answer was proverbial and echoed elsewhere in our discussions: 'They say the husband should raise her with his own hand'. For a bride to be raised like a child by her husband is of course the stark opposite of the bride with her own 'personality' and education that consistently emerged as an ideal. We asked the young women in Sair, none of whom were able to continue to higher education, if university students graduating at 21 or 22 may have a chance at marriage:

Well, if you have a degree and can work, it's OK. If you have only tawjihi [general secondary school 
examination], there is not much hope. We have

'nothing in our hands'.

The young women broadly blame their constrictions on 'the political situation', and the fear it generates among their families. Whether tales of an Israeli soldier forcing a girl to kiss a young man at the Hebron checkpoint, or the story of false pornographic images on mobile phones, the present is full of 'embodied' dangers - and interestingly, the young women look to the past, not the future, for better times. The young women in Sair affirm, 'It wasn't always like this. Things got worse in the Al Aqsa intifada. Families are afraid for their girls and there is no security'.

\section{Tropes of dis-ease and disorder: customary marriage and old men and young brides}

Many young women - and sometimes their mothers as well - identified 'new' and disturbing forms of marriage, particularly the very old marrying the very young, and customary marriage (zawaj urf $i$ - unregistered marriage without a formal marriage contract) as the one danger they face rather than physical peril. This was particularly potent during our meeting in Sair where as we walked up the steep hill, an Israeli army jeep entered the village, boys threw stones, and shots were fired. Such an encounter was, to use a common Palestinian expression with irony, 'aadi' (ordinary), something these young women face daily (Johnson 2007b). In conversation, this 'ordinary' situation of war was ignored while stories of improper marriages as moral disorder predominated.

We thought customary marriage was uncommon in Palestine, yet the subject spontaneously emerged in discussions around local press articles on the rise of youth suicide. Interestingly, students at Hebron University immediately assumed the suicides were female although the account described both male and female deaths. Pressure from families and social and economic reasons were cited. All agreed, however, that one cause was the '... many customary marriages where girls are placed in immoral and deceitful conditions'. One recounted, 'One girl was in an urfi marriage and then she got engaged to someone else. She committed suicide'.

Although the Islamic Sharia allows a form of customary marriage where there is a marriage contract signed by a guardian, zawaj urfi has come to have many other forms, including a secret agreement between the couple only, which would constitute an illicit relation in Sharia terms. The extent and forms of customary marriage have not been explored in the Palestinian context, but the discourse circulating in our discussions points to it both as an emerging phenomenon and a trope for other forms of disorder. 'We never had this before', was an often repeated refrain.

Another key narrative of improper marriage that emerged frequently was old men marrying the very young. In Sair, the material motive for such marriages was prominent: 'Two old men married sisters of 15 and 16. Their families did it just for the money. The old men were rich'. The young women conclude: 'Of course there is force and oppression $[\mathrm{zulm}]$ in making these matches'.

Given that marriages (and weddings, as noted by Johnson et al. 2009) are a highly resonant symbol for social and political harmony - so much so that democratic Palestinian elections were widely described as a 'Palestinian wedding' illicit or improper marriage is an equally resonant symbol for a world out of kilter.

\section{Virtual dangers, actual bodies}

Another striking version of physical insecurity transformed into moral disorder came in Shawawreh. Entering the meeting shortly after the discussion began, Um Nabil was a tall and imposing woman, draped in black, with a strong square face. The black was not for her widowhood but for her brother, who had been assassinated along with three other militants by the Israeli army in Bethlehem a few weeks earlier.

With this death on everyone's mind as a reminder of the insecurity of Palestinian daily life, we were particularly surprised by the unanimous answer when we asked: what were the main dangers to girls in their late teens in the village? The answer came quickly: 'Television - but only satellite television. It is a disaster'.

Everyone agreed with this, although they hastened to say that they are not against satellite television per se, that there are useful educational programmes and they do not even oppose music programmes (thus distancing themselves from some Islamist positions). However, they assert 
there are immoral programmes that disturb young people. Refugee women living in Doha, a suburb just outside Dheisheh refugee camp, were even more emphatic about the dangers of satellite television. A middle-aged women with teenage daughters, when asked why a young girl might kill herself answered 'salsalaat' (soap opera series that are very popular on satellite television) that undermine morals. The notion here is that these series put false ideas about life and morality into the heads of the susceptible young. The women in this particular focus group, mostly mothers of unmarried daughters, seemed to cast these lurid virtual soap opera dangers onto their real streets. As one declared, she trusts her 16-year-old daughter but won't allow her out of the house because, 'I am frightened for her. The shebab [young boys] might talk badly to her. They might give her an acamol [paracetamol] but it is really drugs'.

Other women then contribute stories of alcohol put in a soft drink and given to a teenage girl, and again fake pornographic pictures being circulated by mobile phone. While young men particularly the unemployed and frustrated young men of this period - are certainly occasionally guilty of incidents of sexual harassment, we seem once again to be in the terrain of moral panic and globalised and sexualised dangers conditioned by satellite as well as by the actual and insecure conditions on the streets of Doha and Bethlehem. The sense of a generation gone astray is of course not particular to Palestine but the contrast made with previous generations which stood for national struggle and values - can be striking. One 29-year-old activist in Amari, who had participated as a boy in the popular mobilisation of the first intifada (1988-93) contrasted himself to the teenagers in Amari's youth club: 'We were the generation of intifada, they are the generation of satellite'.

The voices above are countered to some extent by the opinions of young unmarried women themselves about satellite television. Most are eager to distance themselves from its sexualised images. When asked if Nancy Ajram, a very popular and sexy singer on various satellite stations, was someone they admire, young women unanimously rejected her - often with shy laughter. They do note dangers, but often different dangers than the older generation. One young woman from Dheisheh mentioned the risk of believing everything on television:

There was a young woman here in her twenties who went on a diet-just a cup of tea a day-because she saw all the images on satellite TV. Her haemoglobin went to three and she died.

Young women in the Jenin focus group noted young men are not respectful: 'All they think of is sex, not love'. Their behaviour was blamed on the internet. However, young women found solace in religious and educational programmes on satellite television, naming several female sheikhs or religious instructors who they greatly admired - and who address issues of family life, bodily comportment and life goals that young women are eager to understand, and may not find answers from their own families.

In fact, many of the young women in our discussions were uneasy with their knowledge about their bodies and felt they needed more information. A young woman from Sair said, 'We are embarrassed, we don't know about our bodies. When we ask someone says “it's wrong to talk like that" [Eib tehki hek]'.

Young women in Beit Fajjar, however, found mothers more forthcoming, saying they learned about periods from their mothers and that 'It's not like the old days'. And most young women even those who said they couldn't talk about sex - said such talk was not shameful (mish eib) and that girls needed more understanding. Tala from Dheisheh said: 'I am embarrassed but we need to know about married life'. Manal agreed and added, in an equally embarrassed tone: 'Of course we don't want anything silly, it should be scientific'.

The last remark reflects a feeling that that there is a proper, and an improper way to treat sexual matters which is also applied to notions of freedom. Fadia from Jenin refugee camp, after condemning men who tell their wives and daughters that everything is forbidden, hastened to add: 'I am not saying that someone should be just loose and do whatever she wants. There should be a balance'.

The desire for young women to understand their bodies is clearly articulated - as are the barriers to such understanding. One young woman in 
Dheisheh addressed a telling barb to the many NGO activities to 'train' Palestinian youth in democracy: 'Really, we are bored from always having the same subject, communications workshops, democracy. Learning about our bodies would be better'.

\section{Can an unmarried woman be happy?}

While most of the young unmarried women in our discussions continued to see marriage particularly with a sympathetic partner - as an important good, there were voices of dissent about the happiness of married life and the inevitable misery of unmarried women. When asked if an unmarried woman can have a happy life a young woman from the Hebron area village of Tarqumia, had a personal example:

Yes, my aunt stayed unmarried, she was political and taught school. She was happy and went around. She went to Russia when she liked.

Her aunt's trajectory - as a professional, political activist and an autonomous spirit - is typical of most of the life stories of older professional unmarried women recorded in this project, and indeed of even older generations of unmarried Palestinian women who founded schools, charitable societies, and participated in the nationalist movement (Fleischmann 2003). An autonomous life was valued both for its own sake and for the opportunity for public service. Zahira reflected on her life course:

What you want when you are young, you don't when you are older. I value the freedom and space, I don't want to lose it. I am happy with my life. It was my decision [not to marry] and I go with it. If my life was repeated, I will do it again.

Whether young women in both more restricted and contradictory times can find the same fulfilment in a life without marriage, is an open question which the young women in our focus groups addressed in different ways. Most of the young women in Jenin agreed that 'If you are not married, you feel weak'. Some limited their aspirations, 'I don't think of love at all. At 27 or 28 , it is not one hundred per cent that I will find someone'.

Yet they did not necessarily locate the source of the misery in their lack of a spouse, but rather in the community responses to their unmarried state. Unmarried women could be happy, they opined, in certain circumstances, 'Yes if there was no society to say awanes [old maids, spinsters] she could be happy'.

The language is significant: awanes [plural of a'nes] is a term with a strong negative connotation. Perhaps less negative, but certainly telling is the common practice of calling unmarried women, whatever their age 'banaat' (girls), a term also meaning daughters. This infantilisation and desexualisation of unmarried women has the connotation of being excluded from adult femininity (Sa'ar 2004).

Nonetheless, in Beit Fajjar, Basma evoked the authority of the Qur'an, affirming that it says you do not have to get married. And almost all agreed that another key to happiness as an unmarried woman was stable employment. In Shawawreh, a mother defended her two daughters:

An unmarried bint [girl, daughter] can go as she wants. My daughter is 28 years old and she works and buys her clothes and does as she wants. One works in Beit Sahur. There is another one in Abu Dis - bint sharifi [an honourable girl]. Girls today do not marry min makaan [just anybody].

There is thus a long tradition of unmarried women with fulfilled and significant lives that needs to be recovered from the past (Fleischmann 2003) into the present era where unmarried women are increasingly a locus of moral panic and a trope for social disorder. There are also stirrings of change, contradictory and frustrated, but embodied in the determination and thwarted desires of a new generation of young women for a productive and meaningful life.

Two short films made by young unmarried women explore these contradictions, desires and determination. Rahaf examines the effects of a broken engagement on a young girl who is ostracised and condemned. Fadia El Dein, the filmmaker, herself from a village, says:

I passed through this experience and I don't want people to feel sorry for me. People see the girl who has a broken engagement as someone who will be a spinster for life. (Shashat 2008: 16) 
In Remote Control (a short film by Dara Khader), Amal, a student at Al Najah University in Nablus, is being teased by her friends about her devotion to her boyfriend Ahmed when she hears the news that she has received a full scholarship to the USA. Ahmed demands she turn it down.

\section{Notes}

1 Names and some other identifying details have been changed to protect privacy except in the case of the former Minister of Women's Affairs, Zahira Kamal and D. Ilham Abu Ghazaleh, both of whom chose not to be anonymous. Names of women in the focus groups have also been changed.

2 There were ten focus groups conducted by the author and Fadwa Abu Labban with unmarried women aged 19-29 in the West Bank, and nine topical life interviews with unmarried women aged 45-68: seven in the West Bank interviewed by the author and two in Gaza. A special thanks to Andaleeb Udwan for conducting and transcribing the two important interviews in Gaza despite the severe conditions there at the time. The nine topical life stories are examined separately and in more detail in Johnson (2007a).

3 Under the 1995 Oslo Interim Agreement signed between Israel and the PLO, the West Bank was divided into three areas, of which the largest was Area C (about 40 per cent) under sole Israeli security control. Area A (the main Palestinian towns) is under Palestinian security control, while Area B is nominally under joint

\section{References}

Butler, J. (1993) Bodies that Matter: On the Discursive Limits of 'Sex', London: Routledge

Cohen, S. (2002) Folk Devils and Moral Panics, London: Routledge

Drieskens, B. (2006) 'Reasons Not to Marry: Rising Celibacy in Contemporary Beirut', paper presented at the Second World Congress for Middle Eastern Studies, Amman, Jordan, 11-16 June

El-Khoudary, T. (2008) 'For War Widows, Hamas Recruits Army of Husbands', New York Times, 31 October

Fleischmann, E. (2003) The Nation and its 'New'

Women: The Palestinian Women's Movement 1920-1948, Berkeley: University of California Press
Later at home, Amal receives a call from Ahmed who thinks she has refused the scholarship; she tells him she has to think about it. She turns on her laptop, writes an acceptance letter, and presses 'send'. In the last shot, Amal appears sad, reflective - but determined to move.

control, but in fact control is exercised by Israel. The provisions for Area A have been violated repeatedly by Israeli invasions.

4 In 2006, there were 14 honour crimes recorded in Palestine, rising to 18 in 2007 (PICCR 2007, 2008). Almost all were on unmarried women and committed by male members of their natal family. Johnson (2008) explores cases of honour crimes in the larger context of violence against Palestinian women and girls.

5 While the care of an elderly parent or parents is frequently the duty of the unmarried daughter, Basma has embraced her task and also conducts activities for the elderly: 'I give to people, I don't think of myself at all'.

6 Palestine registers unusually low female labour force participation (at about 12 per cent) largely due to gendered and restricted labour markets. It is also true that participation (and approval of the same) rises when conditions are more secure. At present, insecurity and instability has shrunk both the actual labour market - there are fewer jobs for an ever-growing number of young job seekers - and the perceived market of acceptable jobs for women.

Friedl, E. (2003) 'Tribal Enterprises and Marriage Issues in Twentieth Century Iran', in B. Doumani (ed.), Family History in the Middle East: Household, Property and Gender, Berkeley: University of California Press

Ghazi, J. (2006) 'Unmarried Arab Women Chastised by their Societies', New America Media, Pacific News Service, 14 March

Halabi, H. (2007) 'Profile of Single Women in Palestine', Review of Women's Studies 4: 27-46, Birzeit: Institute of Women's Studies, Birzeit University

Ibrahim, M. (2004) 'Alarm Bells Ring as Rate of UAE Spinsters Rise', Khaleej Times, 16 July

Johnson, P. (2008) "Violence All Around Us": Dilemmas of Global and Local Agendas Addressing Violence Against Palestinian 
Women, an Initial Intervention', Cultural Dynamics 20.2: 119-32

Johnson, P. (2007a) 'Palestinian Single Women: Agency, Choice, Responsibility', Review of Women's Studies 4: 47-64, Birzeit: Institute of Women's Studies, Birzeit University

Johnson, P. (2007b) 'Tales of Strength and Danger: Sahar and the Tactics of Everyday Life in Amari Refugee Camp, Palestine', Signs 32.3: 597-620

Johnson, P.; Nahleh, L.A. and Moors, A. (2009)

'Weddings and Wars: Marriage Arrangements and Ceremonies in Two Palestinian Intifadas', Journal of Middle Eastern Women's Studies 5.3: $11-35$

PCBS (2006a) Palestinian Family Health Survey, 2006: Final Report, Ramallah: Palestinian Central Bureau of Statistics

PCBS (2006b) Demographic and Health Survey2006: Final Report, Ramallah: Palestinian Central Bureau of Statistics

PCBS (2004) Demographic and Health Survey - 2004: Final Report, Ramallah: Palestinian Central Bureau of Statistics

PCBS (2002) Family Formation in the Palestinian Territory, Ramallah: Palestinian Central Bureau of Statistics
PCBS (2000) Demographic and Health Survey - 2000: Final Report, Ramallah: Palestinian Central Bureau of Statistics

PICGR (2008) Annual Report 2007, (in Arabic) Ramallah: Palestinian Independent Commission for Citizens' Rights

PICCR (2007) Annual Report 2006, (in Arabic) Ramallah: Palestinian Independent Commission for Citizens' Rights

Rashad, H.; Osman, M. and Roudi-Fahimi, F. (2005) Marriage in the Arab World, September, Washington DC: Population Research Bureau

Rosenfeld, M. (2004) Confronting Occupation: Work, Education and Political Activism of Palestinian Families in a Refugee Camp, Stanford: Stanford University Press

Sa'ar, A. (2004) 'Many Ways of Becoming a Woman: The Case of Unmarried IsraeliPalestinian "Girls"', Ethnology 43.1: 1-18 Shashat (2008) Women's Film Festival in Palestine, Ramallah: Shashat

Weizman, E. (2007) Hollow Land: Israel's Architecture of Occupation, London: Verso 